\title{
OTONOMI DAERAH DAN PENGELOLAAN SUMBERDAYA ALAM : KASUS PENGELOLAAN HUTAN DI SULAWESI SELATAN
}

\author{
Decentralization and Natural Resources Management : \\ Forest Management Case in South Sulawesi
}

Baharuddin Nurkin

\begin{abstract}
Decentralization has been regarded as a best way to utilize natural resources for local people benefit and to distribute development results fairly through out of entirely of the country. However, experience has shown that in some cases decentralization in forest management policy was not implemented by local authorities in balancing way of both utilization and conservation. On the other hand, local government complained that even though power transfer to local authority has been implemented since the Indonesian reform politic, central government is still maintaining control over the forest management policy. This article describes decentralization experiences of forest management policy in South Sulawesi. Their impacts followed by some suggestions are also outlined.
\end{abstract}

Key words : Decentralization, Forest management, Local Authority, Central Goverment

\section{PENDAHULUAN}

Memasuki abad ke 21 kita menghadapi tantangan yang berat dalam pemanfaatan dan pengelolaan sumberdaya alam. Tantangan tersebut sebahagian berasal dari perkembangan global sebagai paradigma baru yang mempengaruhi tatanan ekonomi dan politik internasional. Sebahagian lagi berasal dari dalam negeri yang sedikit banyaknya juga timbul akibat pengaruh global. Tantangan dari luar yang merupakan paradigma baru pengelolaan sumberdaya alam adalah adanya kemauan bersama secara internasional untuk menerapkan prinsip-prinsip pembangunan berkelanjutan sebagaimana telah disepakati pada Pertemuan Puncak Bumi di Rio de Jeneiro pada tahun 1992.

Pembangunan berkelanjutan ini hanya dapat terlaksana apabila didukung oleh perwujudan demokratisasi dan keadilan dalam suatu negara. Dunia internasional dan organisasi internasional mendorong dan menyambut baik upaya-upaya desentralisasi. Otonomi daerah sangat diharapkan untuk mempercepat pembangunan dan hasil-hasilnya bagi masyarakat setempat. Desentralisasi merupakan isu yang penting di negara-negara dunia ketiga sejak tahun 1980an. Bank Dunia melaporkan pada tahun 1999 bahwa lebih kurang $80 \%$ negara-negara sedang berkembang telah melaksanakan desentralisasi dalam berbagai bentuk.

Pelaksanaan desentralisasi yang didambakan dan telah lama ditunggu-tunggu tersebut benar-benar terwujud dengan keluarnya UU No. 22 tahun 1999 tentang Pemerintahan Daerah dan UU No 25 tahun 1999 yang mengatur perimbangan keuangan dalam pelaksanaan otonomi daerah. Kedua UU tersebut telah menyatakan dengan tegas bahwa desentralisasi berada pada level kabupaten.

Sebagaimana dinyatakan dalam pasal 7 dan pasal 10 UU No 22 tahun 1999, daerah mempunyai kewenangan dalam seluruh bidang pemerintahan, kecuali kewenangan dalam bidang politik luar negeri, pertahanan keamanan, peradilan, militer, moneter dan fiskal, agama serta kewenangan bidang lain. Selanjutnya dinyatakan pula bahwa kewenangan bidang lain ini antara lain adalah dalam aspek pendayagunaan sumberdaya alam yang tersedia di berbagai wilayah melalui pengelolaan yang bertanggung jawab memelihara kelestarian lingkungan sesuai peraturan perundang-undangan.

Terjadi pula tantangan yang berasal dari dalam negeri yang mempengaruhi kebijakan pengelolaan sumberdaya alam yaitu terjadinya krisis ekonomi yang menyebabkan kebangkrutan perusahaan-perusahaan dan industri khususnya 
yang memanfatkan sumberdaya alam sebagai bahan baku. Krisis ekonomi kemudian segera diikuiti oleh krisis politik yang ditandai dengan runtuhnya pemerintahan orde baru yang kemudian melahirkan orde reformasi. Orde reformasi yang membawa fajar pembaharuan menghendaki tatanan kehidupan politik, sosial, ekonomi yang benar-benar demokratis dan berkeadilan dalam pemanfaatan sumberdaya alam sejalan dengan tuntutan global.

Tulisan ini disusun berdasarkan studi literatur menyangkut desentralisasi dan implementasinya di daerah. Perwujudan otonomi daerah di wilayah Provinsi Sulawesi Selatan terkait pengelolaan hutan dibahas dengan contohcontoh studi kasus. Kelemahan dan hambatanhambatan beserta dampak pelaksanaan otonomi daerah tersebut diungkapkan pada bagian akhir tulisan ini.

\section{HARAPAN-HARAPAN DARI PELAKSANAAN OTONOMI DAERAH}

Argumentasi pokok untuk menjawab pertanyaan mengapa diperlukan otonomi daerah atau desentralisasi dapat dijawab dengan mengacu pada adanya beberapa keragaman dari setiap daerah. Dengan desentralisasi maka pemerintah pusat dapat mengetahui secara jelas apa yang diperlukan oleh daerah untuk meningkatkan kesejahteraan masyarakatnya. Setiap wilayah di daerah-daerah mempunyai keunikan tersendiri dalam banyak hal seperti geografi, budaya, tingkat perkembangan ekonomi, potensi sumberdaya alam dan sebagainya. Tidak ada pemerintahan secara terpusat yang dapat membuat kebijakan dan program yang sama untuk setiap daerah untuk mencapai sasaran secara tepat. Karena itu melalui desentralisasi diharapkan masing-masing pemerintahan di setiap daerah dapat mengatasi permasalahannya dan memberi prioritas apa yang akan dikembangkan karena mereka sendiri yang mengetahui secara baik potensi alam yang tersedia beserta keinginan dan harapan-harapan masyarakatnya.

Desentralisasi dengan demikian dapat kita tafsirkan sebagai suatu keputusan politik dalam pelaksanaan demokratisasi dan keadilan sebagaimana dicita-citakan dalam era reformasi ini. Dalam kaitan ini desentralisasi adalah upaya secara sadar oleh negara untuk mengalihkan secara nyata kekuasaan dalam pengambilan keputusan dari tingkat pusat ke daerah.
Berikutnya yang diharapkan dari desentralisasi adalah memperpendek jalur komunikasi antara masyarakat dengan pemerintah. Dalam hal ini adalah agar masyarakat lebih dekat ke pihak birokrasi sehingga masyarakat lebih cepat mendapat pelayanan dan lebih cepat menyampaikan aspirasinya kepada aparat pemerintah.

Selanjutnya dengan adanya desentralisasi maka kemampuan masyarakat dan sumberdaya yang ada dapat dimobilisasi dengan lebih baik. Dengan cara seperti ini maka program seperti pendidikan, pelayanan kesehatan, upaya rehabilitasi hutan dan lahan, dan pembangunan pertanian dapat direalisasi lebih cepat dan lebih terarah. Bertumpu pada kemampuan lokal dari masyarakat dan sumberdaya ini maka upaya menolong diri sendiri akan lebih menonjol dalam mengatasi masalah lokal, tidak tergantung kepada bantuan dari pusat dan dari luar.

\section{DAMPAK IMPLEMENTASI OTONOMI DAERAH DAN BEBERAPA CONTOH KASUS TERKAIT DENGAN PEMANFAATAN DAN PENGELOLAAN SUMBERDAYA ALAM DI SULAWESI SELATAN}

Dengan desentralisasi, pemerintah daerah (PEMDA) diharapkan mempercepat peningkatan kesejahteraan masyarakat dalam menerapkan dan mewujudkan pengelolaan sumberdaya alam yang lebih baik karena para pengambil keputusan berada dan lebih dekat dengan masyarakat setempat. PEMDA dianggap lebih mengetahui persoalan dan kebutuhan masyarakat di daerahnya sendiri dibandingkan dengan pemerintah pusat. Dengan demikian desentralisasi akan mewujudkan pembangunan yang lebih partisipatif, peningkatan pemerataan pendapatan masyarakat lokal dari hasil pemanfaatan sumberdaya alam dan diharapkan pula untuk lebih bertanggung jawab dalam penerapan prinsip-prinsip keberlanjutan dalam pengelolaan sumberdaya alam dan lingkungan hidup di daerahnya. Walaupun demikian terdapat beberapa kelemahan dari penerapan desentralisasi yang dapat menyebabkan penyimpangan,

1. apabila tidak disertai tanggung jawab dalam kewenangan dan kemampuan dalam pengelolaan serta dukungan kapasitas kelembagaan yang memadai 
2. kecenderungan untuk meningkatkan pendapatan daerah menyebabkan pengurasan dan ketidakberlanjutan pemanfataan sumberdaya alam.

3. eksternalitas yang timbul tidak hanya merugikan satu sektor atau daerah itu sendiri tetapi menyebabkan kerugian yang bersifat multisektor dan melampaui batas-batas administratif suatu daerah hingga memberikan dampak yang bersifat regional bahkan nasional.

Sebagai contoh penyimpangan dari proses desentralisasi adalah timbulnya kebebasan yang tidak terkendali dari pemerintah-pemerintah daerah termasuk dalam pemanfaatan sumberdaya alam berupa hutan yang ada di dalam wilayah administratif mereka. Karena merasa memiliki kewenangan serta didorong oleh keinginan yag besar untuk memperoleh dan meningkatkan pendapatan asli daerah (PAD) maka pemerintah daerah kemudian berusaha memanfaatkan potensi sumberdaya hutan yang berada di daerahnya masing-masing. Sumberdaya hutan dipilih untuk disajikan di sini karena hutan merupakan sumberdaya yang bersifat strategis. Pemanfaatan dan pengelolaannya mempengaruhi mutu dan pendayagunaan sumberdaya alam lainnya. Kerusakan hutan memberikan konsekuensi yang luas terhadap sumberdaya air, produktivitas pertanian, dan membawa ancaman terhadap lingkungan hidup yang tidak terbatas pada wilayah administratif dimana hutan tersebut berada. Kasus degradasi hutan dalam era otonomi daerah paling menonjol dan secara luas banyak terjadi di Indonesia termasuk di Propinsi Sulawesi Selatan.

Dengan dikeluarkannya PP No.25 tahun 2000 yang antara lain mengatur kewenangan pemerintah dan kewenangan propinsi sebagai daerah otonom dalam pengelolaan hutan dimulailah era baru yang diharapkan dapat menjabarkan pelaksanaan pengelolaan hutan dalam kerangka pemberlakuan UU No. 22 tahun 1999. Tugas dan kewenangan urusan kehutanan diatur dalam PP ini. Penggarisan yang menonjol dari PP ini adalah bahwa pemerintah menyiapkan dan menetapkan standar dan kriteria. Sedangkan pemerintah propinsi bertugas membuat pedoman bagi pelaksanaan pengelolaan di tingkat kabupaten. Disamping itu pemerintah propinsi bertugas melaksanakan pengawasan dan perlindungan terhadap kawasan hutan lintas kabupaten.
Namun nampaknya masih diperlukan lebih banyak lagi berbagai regulasi yang lebih spesifik dan mendetail (PP, Kepres, Kepmen atau Perda) untuk menjabarkan bagaimana teknis operasional UU No. 22 tahun 1999 dan UU No. 25 tahun 1999 tersebut beserta UU yang terkait dengan kehutanan (UU No. 41 tahun 1999) agar tersedia landasan hukum bagi pelaksanaan desentralisasi sehingga pelaksanaannya jelas dan tidak mengandung banyak tafsiran yang berbeda. Hal ini sangat ditekankan mengingat banyak menimbulkan kontradiksi kelembagaan dan pelaksanaan pemanfaatan dan pengelolaan sumberdaya hutan di daerah. Beberapa penyimpangan yang terjadi antara lain,

1. penempatan para staf atau pegawai dan aset dari lembaga yang dibubarkan atau dilebur. Pegawai yang mempunyai keterampilan teknis lebih banyak menumpuk di tingkat propinsi. Di daerah terjadi kekurangan tenaga profesional yang diperparah dengan rekruitment pegawai oleh PEMDA yang tidak mempunyai latar belakang pendidikan kehutanan.

2. peranan dan tanggung jawab lembaga atau instansi di daerah (tingkat propinsi dan kabupaten) tumpang tindih, tidak sejalan, atau bertentangan.

3. perselisihan dan konflik terhadap alokasi pengunaan lahan hutan.

4. berkembang dan tidak terkendalinya perambahan hutan dan illegal loging (tebangan liar).

Dalam aktualisasi pelaksanaannya kewenangan yang tertuang dalam UU otonomi daerah tahun 1999 tersebut terjadi beberapa hal yang bersifat distorsi dan menyimpang dari tujuan pengelolaan dan pemanfaatan hutan. Misalnya saja seperti yang pernah terjadi di Kalimantan Timur pada tahun 2000 dimana pemerintah daerah kabupaten memberikan izin hak pengusahan hutan dalam skala tidak lebih dari 100 ha. Di Papua juga dikeluarkan izin penebangan hutan skala kecil yang mengakibatkan terjadinya pula penebangan tak terkendali yang cenderung merusak. Sampai saat ini walaupun sudah ada larangan, praktekpraktek seperti ini masih berjalan terus (Kompas 11 Desember 2003). Banyak hal yang menjadi penyebab dari masalah ini antara lain adalah perbedaan dalam penafsiran kewenangan pusat dan daerah demikian juga adanya keterbatasan sumberdaya manusia dimana aparat yang memiliki keterampilan teknis dan pengelolaan masih 
bertumpuk pada kantor-kantor pemerintahan tingkat propinsi.

Akibat dari illegal loging tidak hanya mengancam pelestarian hutan produksi tetapi yang lebih memprihatinkan adalah terjadinya kerusakan pada hutan-hutan yang mempunyai fungsi lindung. Data menunjukkan bahwa $38 \%$ areal taman nasional yang ada dan $46 \%$ areal hutan lindung lainnya mengalami degradasi (WFC, 1997 dalam Che Yeom dan Chandrasekharam, 2002).

Nampaknya proses desentralisasi dilaksanakan terlalu terburu-buru, mungkin didorong oleh semangat reformasi dengan maksud dan tujuan yang baik dan telah lama dirindukan rakyat di daerah. Namun tidak disertai penyiapan kapasitas yang mendukung proses tersebut pada tingkat kabupaten yang pada akhirnya berimplikasi pada pengelolaan sumberdaya alam.

Studi yang dilakukan oleh Center for International Forestry Research (CIFOR) bekerjasama dengan Jurusan Kehutanan Fakultas Pertanian dan Kehutanan UNHAS (CIFOR dan Jurusan Kehutanan UNHAS, 2003) mengungkapkan beberapa dampak yang terjadi dalam masalah pengelolaan hutan pada awal era otonomi daerah di Kabupaten Luwu Utara dan Kabupaten Mamuju. Dari hasil penelitian terungkap bahwa terdapat berbagai kerancuan kewenangan yang dilimpahkan ke daerah kabupaten demikian juga terjadi perbedaan interpretasi antara propinsi dan kabupaten dalam menginterpretasikan perundang-undangan yang terkait dengan otonomi daerah tersebut. Dalam berbagai kasus terjadi penafsiran yang cenderung menguntungkan masing-masing level pemerintahan. Pemerintah kabupaten menyambut dengan cepat pemberlakukan otonomi daerah dengan membuat PERDA yang menguntungkan dirinya dan dilain pihak pemerintah pusat secara kontinyu masih terus melakukan regulasi yang mungkin membatasi ruang gerak PERDA tersebut. Pembahasan di DPRD tentang regulasi lokal kadang-kadang terhambat karena keluarnya peraturan perundangan yang lebih tinggi yang akan dijadikan acuan telah mengalami perubahan.

Hal lainnya yang ditemukan dari penelitian ini adalah adanya keluhan dalam masalah pengalokasian dana perimbangan yang kurang adil dan turunnya anggaran tersebut tidak tepat waktu. Dana rehabilitasi hutan yang dialokasikan dari pemerintah dirasakan oleh kedua kabupaten ini tidak adil dan tidak seimbang. Alasan yang dikemukakan adalah hanya dua daerah tersebut yang memberi kontribusi pendapatan kepada pemerintah pusat dari hasil pemanfaatan hasil hutan dari hutan produksi yang dimilikinya, tetapi dana rehabilitasi yang diterima dari pemerintah pusat tidak jauh berbeda dengan yang dialokasikan bagi daerah-daerah lainnya di Propinsi Sulawesi Selatan.

Perselisihan dalam penetapan lokasi kegiatan rehabilitasi juga banyak dipermasalahkan antara Dinas Kehutanan Propinsi dan Dinas atau instansi Kehutanan tingkat kabupaten. Penetapan lokasi yang direncanakan untuk reboisasi lebih banyak dilakukan oleh instansi tingkat propinsi. Bahkan kadang-kadang instansi kehutanan di daerah kabupaten tidak mengetahui adanya program seperti ini yang akan dilaksanakan di daerahnya.

Kecenderungan terjadinya konversi lahan hutan yang memang telah banyak terjadi sebelum desentralisasi terasa semakin meningkat intensitasnya dalam era otonomi daerah. Hal ini disebabkan adanya kebutuhan lahan bagi perluasan tanaman perkebunan atau komoditas hortikultura. Contoh seperti ini terjadi hampir di seluruh kabupaten di Sulawesi Selatan untuk perluasan tanaman sayur-sayuran, kentang, kopi, dan kakao. Lahan hutan yang ditumbuhi pohonpohon hutan tanaman juga banyak diokupasi untuk memanfaatkan ruang kosong di bawah tegakan untuk tanaman kopi.

Di Luwu Utara, kelompok masyarakat menyatakan klaim pemilikan lahan yang mereka nyatakan sebagai lahan adat yang pada jaman orde baru dimasukkan sebagai bagian dari kawasan hutan lindung. Klaim ini mencakup luas areal 7500 ha. Upaya untuk menuntut lahan ini rupanya baru dikemukakan dalam era otonomi daerah yang memberikan lebih banyak kebebasan bagi masyarakat untuk menuntut hak-haknya.

Contoh lain dari pemanfaatan sumberdaya alam di luar sektor kehutanan yang tidak terkendali di berbagai daerah di Sulawesi Selatan yang menimbulkan dampak lingkungan yang serius dan konflik antara masyarakat dan PEMDA adalah pemanfaatan bahan tambang golongan $\mathrm{C}$. Malahan perizinan untuk pemanfaatan bahan tambang seperti ini dikeluarkan oleh PEMDA di kabupaten sebelum keluarnya kedua UU menyangkut otonomi daerah. Pendapatan daerah dari pemanfaatan bahan tambang seperti pasir dan kerikil telah memberikan pendapatan yang cukup lumayan bagi PEMDA setempat. Sebagai contoh kabupaten Gowa mendapat penerimaan lebih dari 
Rp. 5 milyar rupiah pertahun sebagai pendapatan asli daerah. Namun sebagai dampak dari penambangan ini adalah terjadinya kerusakan vegetasi alam, kerusakan pada lahan pertanian dan pemukiman pada dan di sekitar bantaran sungai, meningkatkan muatan sedimen dalam air sungai, hilangnya sumber air, gangguan tempat pemijahan berbagai jenis ikan, terjadi banjir karena aliran sungai berubah dan tidak terkendali pada musim hujan serta menurunkan nilai estetika. Bahkan mengakibatkan kerusakan pada bangunan penting antara lain jembatan (Martens, 1999; PPLH UNHAS, 2000).

\section{PENUTUP}

Terlihat dalam implementasinya desentralisasi dapat mengalami beberapa hambatan yang diakibatkan oleh beberapa hal. Masih terlihat keengganan dari pemerintah pusat untuk menyerahkan kewenangan. Pemerintah daerah mungkin secara formal telah menerima mandat untuk melaksanakan kewenangan namun masih banyak pembatasan dan hambatan dalam melaksanakan kewenangan tersebut. Dalam hal ini masih ada bayang-bayang rantai komando birokrasi dari atas ke bawah secara samar-samar namun pengaruhnya nyata. Kedua mungkin saja otonomi telah berlaku di suatu daerah, namun pemerintahan lokal sendiri tidak efektif menggunakan kewenangan yang telah dilimpahkan. Hal ini dapat dilihat dari ketidakmampuan untuk membuat perencanaan pembangunan yang baik, tidak mempunyai monitoring kemajuan pelaksanaan pemerintahan, gagal membuat rencana anggaran yang berimbang yang menyebabkan masih adanya ketergantungan pada bantuan keuangan dari pusat. Apabila bantuan dari pemerintah pusat terbatas maka upaya untuk mencukupkan anggaran kemudian ditempuh dengan mengejar dan menambah pendapat asli daerah dari berbagai sumber termasuk memanfaatkan sumberdaya alam yang tersedia dengan dampak lingkungan dan sosial yang tidak terkendali. Karena itu dalam rangka pemanfaatan sumberdaya alam dalam pelaksanaan otonomi daerah diperlukan pengendalian dengan cara,

1. membuat pedoman yang jelas dan rinci (PP, Kepmen, PERDA) tentang hak, peranan dan kewajiban dari pemerintah, pengusaha, dan masyarakat utamanya bagi yang berada pada lokasi sumberdaya alam yang akan dimanfaatkan.

2. membuat pedoman yang berada dalam kerangka nasional dan global untuk menjamin konservasi dan pemanfaatan berkelanjutan yang melibatkan secara aktif masyarakat dan pihak swasta setempat.

3. menyiapkan pedoman pemanfaatan sumberdaya alam dengan mengacu pada metoda baku yang menjamin pelestarian. Kajian yang komprehensif terhadap dampak sosial ekonomi dan lingkungan perlu dilakukan sebelum dilaksanakannya pemanfaatan.

Untuk mencegah dampak lingkungan dan sosial yang melampaui batas-batas daerahnya PEMDA diharapkan dapat menerapkan prinsipprinsip dasar pengelolaan sumberdaya yang memperhatikan,

1. prinsip tanggung jawab terhadap kerusakan lintas batas.

Sumberdaya alam tidak hanya merupakan komponen yang penting bagi ekosistem, namun komponen ini juga besar kemungkinan dimiliki oleh berbagai bagian daerah dalam lingkup propinsi bahkan mencakup wilayah nasional dan seterusnya dalam skala internasional. Dengan demikian pengelolaan di suatu wilayah seperti pemanfaatan hutan di wilayah pegunungan atau penangkapan ikan di suatu wilayah perairan dan pengendalian pencemaran laut dapat membawa implikasi tapal batas. Karena itu pengelola sumberdaya alam di daerah harus bertangung jawab untuk mewujudkan pencegahan kerusakan yang dapat berpengaruh atau meluas melampaui batas-batas wilayah pengelolaannya.

2. Rasionalisasi dan persamaan pemanfaatan sumberdaya.

Banyak regulasi nasional dan internasional yang memasukkan prinsip penggunaan dan pengelolaan sumberdaya alam agar sebaiknya dilakukan secara rasional. Di sini ditekankan agar rasionalisasi tersebut dapat memberikan kesadaran terhadap pengguna sumberdaya dari berbagai daerah untuk merundingkan pemanfaatan secara adil di antara mereka. Prinsip seperti ini dapat dimasukkan dalam regulasi nasional (undang-undang) sehingga dapat dijadikan dasar dalam pengambilan keputusan apabila menghadapi masalahmasalah penggunaan sumberdaya yang membawa perselisihan antar daerah atau kabupaten. 
Dengan demikian maka pelaksanaan pengelolaan hutan dan sumberdaya alam lainnya di daerah perlu memperhatikan kaidah-kaidah yang telah disepakati nasional. Hal ini harus dilaksanakan karena upaya membangun keberlanjutan ekonomi nasional sangat tergantung pada hasil yang dicapai melalui kerjasama antar daerah dan nasional. Tidak ada daerah yang benar-benar terisolir dan dapat bekerja sendiri untuk menjaga pelestarian hutan atau melindungi sumberdaya hayati, atau pencemaran laut yang ada di dalam batas-batas teritorialnya yang kesemuanya ini disebabkan oleh saling ketergantungan diantara semua daerah. Saling ketergantungan tersebut tidak hanya disebabkan karena adanya hubungan secara geografi dari lintas jalur melalui daratan, laut atau udara namun juga karena adanya perdagangan, kegiatan pariwisata, kontak sosial dan budaya, serta komunikasi yang sangat pesat perkembangannya. Namun alasan yang utama adalah adanya satu kesatuan sistem kehidupan bersama yang harus dipertahankan demi kelangsungan hidup bersama.

\section{DAFTAR PUSTAKA}

Che Yeom, F.B. dan C. Chandrasekharam. 2002. Achieving sustainable forest management in Indonesia. Tropical Forest Update (12): 1.

CIFOR dan Jurusan Kehutanan UNHAS. 2003. Laporan Pendahuluan Implementasi Desentralisasi Kebijakan Sektor Kehutanan dan Respon Masyarakat. Studi Kasus di Kabupaten Luwu Utara dan Mamuju, Sulawesi Selatan.

Kompas 11 Desember 2003. Pemegang HPHH dan IPK masih beroperasi.

Martens, H. 1999. Environmental Assessment and Proposed Management of Small Scale Mining in South Sulawesi. Dalam : Prosiding Seminar Industri Pertambangan dan Pengelolaan Lingkungan Hidup di Ujung Pandang 27 September 1999. Pusat Studi Lingkungan Universitas Hasanuddin.

PPLH (Pusat Penelitian Lingkungan Hidup) UNHAS. 2000. Laporan Studi Pengelolaan Terpadu DAS Jeneberang. PPLH UNHAS, Ujung Pandang.

Diterima : 27 Desember 2005

\section{Baharuddin Nurkin}

Lab. Silvikultur, Jurusan Kehutanan, Universitas Hasanuddin

Kampus Tamalanrea, Jl. Perintis Kemerdekaan Km. 10, Makassar 90245

Telp./Fax. 0411-585917. Indonesia 